\title{
SIMULATION OF THE EFFECT OF DEFICIT IRRIGATION SCHEMES ON TOMATO CROP PRODUCTION USING AQUACROP MODEL
}

\section{Zeinab M. Hendy*, Samar M. Attaher**, Salama A. Abdelhady***, Ahmed A. Abdel-Aziz* and Abd El Ghany M. El-Gindy*}

\section{ABSTRACT}

The current study investigates the possablities to improve irrigation water productivity of tomato crop, as one of the most important vegetable crops in Egypt, by applying different deficit irrigation scheme. Field experiment was carried out at the Vegatable Farm of the Faculty of Agriculture-Ain Shams University, througthout two seasons 2015/2016 and 2016/2017, on tomato crop under drip irrigation system. Five irrigation treatments, included: (i) 100\% ET [T100], (ii) Application of deficit irrigation level $80 \% E T_{c}$ at all crop growing stages [TC80], (iii) Application of deficit irrigation level $80 \%$ ET $_{c}$ at initial and maturity crop stages only [TS80], (iv) Application of deficit irrigation level 60\% ET at all crop growing stages [TC60], (v) Application of deficit irrigation level $60 \% E T_{c}$ at initial and maturity crop stages only [TS60].

The results showed that, among the investigated deficit irrigation schemes, applying diffecit irrigation schemes of $80 \%$ ET $_{c}$ could reduce the amount of the irrigation water by $20 \%$ when it was applied at all crop growing stages, coupled with a yield reduction of about 17\%, and a slight increase in water productivity [WP] (dividing dry matter of the yield to the ET $T_{c}$ ) by about 2\%. Whereas the same deficit level could save about $16 \%$ of the applied water when it was applied only at initial and maturity growth stages, and decreased the crop yield by 5\%, which gave the highest WP of $2.15 \mathrm{~kg} / \mathrm{m}^{3}$, compared to the other investigated irrigation treatments.

Regarding the AquaCrop model simulation, the results showed that, considering good calibration process, AquaCrop model revealed a very good performance in simulating the tomato crop biomass, and yield.

\footnotetext{
* Agric. Eng. Dept., Fac. of Agric., Ain Shams Univ. Cairo, Egypt

** Agric. Eng. Research Institute (AEnRI), Agricultural Research Center (ARC) Cairo, Egypt *** Hort. Dept., Fac. of Agric., Ain Shams Univ. Cairo, Egypt
} 
This could encourage addressing AquaCrop model as a good tool that can be used with a high degree of reliability in practical management, strategic planning of irrigation, and water limited conditions in Egypt.

\section{INTRODUCTION}

W ater shortage is a critical problem that is continuously increasing, due to population growth, unsustainable usage of water resources, and the projected climate and enviriomental changes. The impact of water shortage is more noticeable in arid regions, and has higher impacts over remote regions and communities, especially in developing countries. Egypt is one of the countries that is facing a serioues water shortage, due to it's limited water resources, coupled with the rapied increase in water demands, and has to do more with less water (Allam et al., 2005). Based on the fact that the agricultural sector consumes about $80 \%$ of Egypt's water resources (MWRI, 2016), improving on-farm water productivity is a vital goal to sustain food and water securities at the national level (Ragab, 2014).

Deficit irrigation is a water-saving strategy which crop is exposed to a particular level of water stress (below the crop evapotranspiration requirements) during a particular period or through the whole growing season (Pereira et al., 2002). The main goal of deficit irrigation is to increase crop water productivity by reducing the amount of water applied to the crop (Fereres and Soriano, 2007). Several studies have shown that one of the encouraging irrigation strategies might be deficit irrigation (e.g.; Fereres and Soriano, 2007; Farre and Faci, 2009; Ahmadi et. al., 2015), since less water than required is applied during the growing period.

Tomato is one of the most widly grown vegtables in the world because of special nutritive value of its fruit. Egypt is one of the main tomato producers in the world, that the crop is occyping about $4 \%$ of the total annual cultivated area, and producing about 7.8 million ton annualy (MALR, 2017). Aiming to sustian the national production goals of tomato crop under the current water statues of Egypt, irrigation management should focused on water saving, maintaining yield and enhancing fruit quality. (El-Gindy et. al., 2007). 
In this regard, investigating the plant response to different irrigation strategies in field and carried out experiments is difficult and expensive. Considering this kind of limitations, accurate crop development models are important tools in evaluating the effects of water deficits on crop yield or productivity, and predicting yields to optimize irrigation under limited available water for enhanced sustainability and profitable production (Pereira et al., 2009). The FAO crop model "AquaCrop" (Steduto et al., 2009), simulates attainable yields of major crops as a function of water consumption under rainfed, supplemental, deficit, and full irrigation conditions. The growth engine of AquaCrop is water-driven, in that transpiration is calculated first and translated into biomass using a conservative, crop-specific parameter (Geerts et al., 2009), the biomass water productivity, normalized for atmospheric evaporative demand and air $\mathrm{CO}_{2}$ concentration. The model uses canopy ground cover instead of leaf area index (LAI) as the basis to calculate transpiration and to separate soil evaporation from transpiration. Crop yield is calculated as the product of above-ground dry biomass and harvest index (HI). AquaCrop uses a relatively small number of parameters and attempts to balance simplicity, accuracy, and robustness (Steduto et al., 2009). Since the year 2009, the model has been evaluated and calibrated in a wide number of studies covered a wide range of crops and strategies for arid and semi-arid conditions, and other water scarcity case studies (e.g.; Stricevic et al., 2011; Attaher, 2012; Toumi et al., 2016).

This study is aiming to investigate different possibilities to improve the irrigation crop-water productivity of tomato crop as one of the most important vegetable crops in Egypt. This main objective is planned to be achieved by investigating the actual effect of applying different deficit irrigation schemes on the growth parameters and the yield of tomato crop. Furthermore, a calibration of AquaCrop model to simulate the effect of deficit irrigation schemes on tomato crop, under the local current conditions, is conducted aiming to present AquaCrop as an evaluated and calibrated tool, to be used for further studies concerned with the impacts of climate change and water shortage on the productivity of tomato crop in Egypt. 


\section{MATERIALS AND METHODS}

\section{Field experiment description and site characterization}

The effect of applying different deficit irrigation schemes on tomato crop production was investigated by conducting field experiment, in the Experimental Farm of the Faculty of Agriculture- Ain Shams University, in Shoubra El-khima district- Qalyoubia Governorate $\left(30^{\circ} 5,10^{\prime}\right.$ N latitude, $31^{\circ} 12^{\prime} 44^{\prime \prime}$ E longitude, and $70 \mathrm{~m}$ altitude). The soil of the experimental field was classified as "clay loam" for the upper soil layer of 0-30 cm depth, where the lower soil layer under $30 \mathrm{~cm}$ depth was "clay". Table (1) shows the mechanical analysis and soil-water parameters that were determined from the laboratory analysis of the soil samples from the experimental site.

Table (1): Mechanical analysis and soil-water parameters of soil samples at Shoubra El khima site, Qalyoubia

\begin{tabular}{lcccc}
\hline \multirow{2}{*}{ Soil properties } & \multicolumn{5}{c}{ sample depth [cm] } \\
\cline { 2 - 5 } Texture & $0-15$ & $15-30$ & $30-45$ & $45-60$ \\
\hline Clay [\%] & Clay & Clay & Clay & Clay \\
Silt [\%] & loam & loam & & \\
Sand [\%] & 32.8 & 35.1 & 41.1 & 42.2 \\
FC (v/v) & 41.2 & 38.8 & 33.6 & 33.2 \\
WP (v/v) & 26.0 & 26.1 & 25.3 & 24.6 \\
Bulk density $\left(\mathrm{g} / \mathrm{cm}^{3}\right)$ & 35.5 & 36.3 & 38.6 & 39.1 \\
pH & 20.7 & 21.7 & 25.0 & 25.5 \\
EC [dS/m] & 7.37 & 1.36 & 1.36 & 1.35 \\
\hline
\end{tabular}

Tomato plants (Lycopersicum esculentum), with variety "Elisa F1" were transplanted manually, throughout two winter seasons, at $10^{\text {th }}$ October 2015 for the first season, and $1^{\text {st }}$ October, 2016 for the second season. The plants were transplanted at $1.2 \mathrm{~m}$ wide and $0.25 \mathrm{~m}$ height soil beds. Each bed had two rows, with $0.5 \mathrm{~m}$ distance plant spacing, and $1.0 \mathrm{~m}$ between rows. Tomato plants were irrigated by drip irrigation system, with PE laterals of $16 \mathrm{~mm}$ built-in drip lines, $4 \mathrm{l} / \mathrm{h}$ discharge, and $0.3 \mathrm{~m}$ spacing. Seasonal on-farm management practices of soil preparation, fertilization, and plant protection were performed through the experiment according to the recommendations of the Ministry of Agriculture and land reclamation. 
The tomato plants were harvested at $10^{\text {th }}$ of March 2016 (after 152 days' season length), and $27^{\text {th }}$ of February 2017 (after 149 days' season length), at the first and second seasons, respectively.

The experiment included five irrigation treatments, consisted of three irrigation levels, and two deficit irrigation application schemes. The overall irrigation treatments included: (i) $100 \% \mathrm{ET}_{\mathrm{c}}$ [T100], (ii) application of deficit irrigation level $80 \% \mathrm{ET}_{\mathrm{c}}$ at all crop growing stages [TC80], (iii) application of deficit irrigation level $80 \% \mathrm{ET}_{\mathrm{c}}$ at initial and maturity crop stages [TS80], (iv) application of deficit irrigation level 60\% $\mathrm{ET}_{\mathrm{c}}$ at all crop growing stages [TC60], and (v) application of deficit irrigation level $60 \% \mathrm{ET}_{\mathrm{c}}$ at initial and maturity crop stages only [TS60]. The five irrigation treatments were investigated in randomized complete block design experiment, with three replications, distributed into 18 experimental plots with $21 \mathrm{~m}^{2}$ area $(3 \mathrm{~m} \times 7 \mathrm{~m})$ for each, and total experimental area of $420 \mathrm{~m}^{2}(20 \mathrm{~m} \times 21 \mathrm{~m})$.

Daily weather data, including daily maximum and minimum air temperature $\left[{ }^{\circ} \mathrm{C}\right]$ ( $\mathrm{T}$ max and $\mathrm{T}$ min), the maximum and minimum relative humidity [\%] (RH max and RH min), and the average wind speed [m/s] at a height of $2 \mathrm{~m}$ above soil surface, were collected from the Central Laboratory for Agricultural Climate (CLAC). Table (2) shows the monthly average of the weather parameters during the growing seasons. The irrigation water requirements were determined along the seasons, based on estimating the "crop evapotranspiration $\left(\mathrm{ET}_{\mathrm{c}}\right)$ " as the product of reference evapotranspiration $\left(\mathrm{ET}_{\mathrm{o}}\right)$ and a crop coefficient factor $(\mathrm{Kc})$.

The daily $\mathrm{ET}_{\mathrm{o}}$ was calculated from daily weather data, based on the standard FAO-Penman Method described in (Allen et al.,1998), by using "ET, Calculator" software (FAO, 2012). The used Kc factors, were the same values referenced for tomato crop in Allen et. al (1998), whereas, the lengths of the growth stages were modified according to the actual data collected from the experiment. The initial $\mathrm{Kc}$ value was 0.6 , reached to 1.15 at the "mid-season" stage, and then declined to 0.8 at the "late season" stage. Day-to-day irrigation schedule was determined based on the soil water content, which was measured by taking daily measures using PMS- 
714 Lutron soil moisture meter (Lutron Electronic) for each plot at $30 \mathrm{~cm}$ depths under the emitter.

Table (2): The monthly average weather parameters for the tomato growing seasons 2015/2016 and 2016/2017.

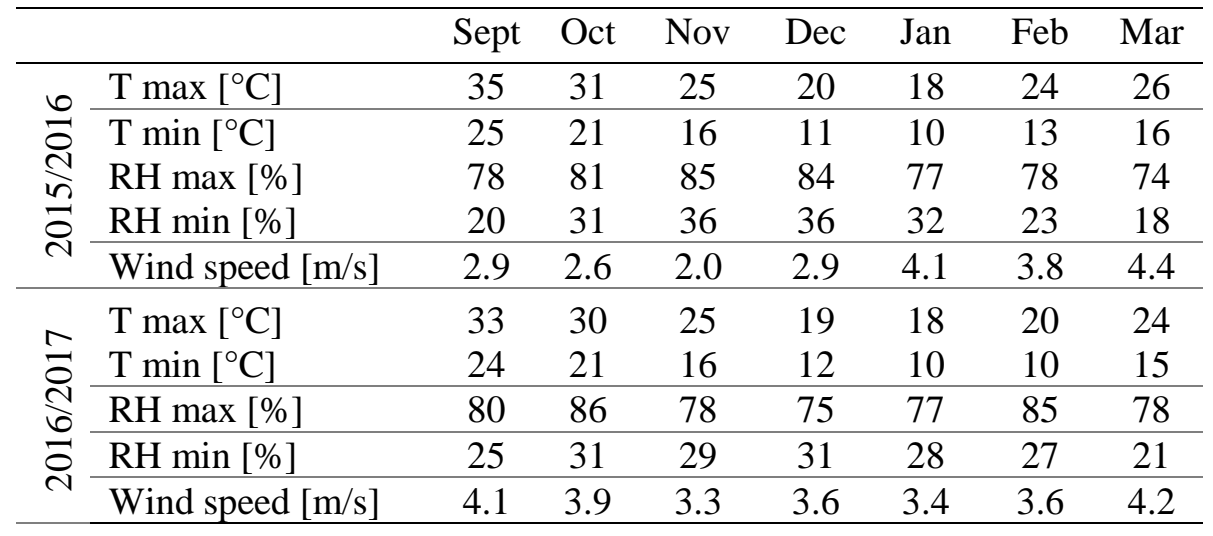

\section{Data collection and measurements}

The duration of each growth stage, as a number of days after planting (DAP), was one of the important observed parameters monitored during the two seasons, in order to estimate the actual crop life-cycle pattern of the tomato plants. Reference to the standard physiological and phenological characteristics of tomato plants, five growth stages were observed during the season as (i) transplant recovery stage, (ii) reaching to maximum canopy stage, (iii) flowering stage, (iv) senescence stage, and (v) maturity stage. Additionally, the number of days after transplanting to maximum root depth, and the maximum effective root depth [m] were observed and measured by taking two plant samples every two weeks. The root depth was measured by using manual method as gentle digging around plant samples and using fine brush and scale meter to recognize plant root distribution and measure its actual depth in the soil.

The total crop yield was measured as a fresh and dry weight of the total matured fruits collected from ten selected plants in each plot, till the harvesting date. The dry weight of biomass and yield was estimated after drying the plants and fruits samples in the oven at $60^{\circ} \mathrm{C}$ for 72 hours. The "Harvest Index (HI) was determined as the percentage of the total dry yield $(\mathrm{kg} / \mathrm{fed})$ to the maximum total above ground dry biomass $(\mathrm{kg} / \mathrm{fed})$. 
Regarding the impact of the irrigation treatments on the fruits quality, total soluble solids (TSS, ${ }^{\circ}$ Brix), was measured with Fisherbrand ${ }^{\mathrm{TM}}$ handheld Brix Refractometer. Moreover, vitamin C (mg $100 \mathrm{~g}-1 \mathrm{FW}$, as ascorbic acid) was determined by titration of homogenate tomato samples (diluted in a 3\% meta-phosphoric acid solution and $48 \%$ acetic acid solution) using a 2.6 dichlorophenol-indophenol solution standardized in a solution of ascorbic acid with a known concentration (AOAC, 1984).

The yield response to irrigation treatments was described in this study by the "dry-yield water productivity" [WP] $\left(\mathrm{kg} / \mathrm{m}^{3}\right)$, that was calculated by dividing the total dry yield $(\mathrm{kg} / \mathrm{fed})$ of the total seasonal $\mathrm{ET}_{\mathrm{c}}\left(\mathrm{m}^{3} /\right.$ season) (Molden et al., 2010).

The analysis of variance [ANOVA] test, was used for statistical evaluation aiming to investigate the significant effects of the applied irrigation treatments on the actual tomato crop yield, water productivity, and fruits quality. The least significant difference (LSD) was used to compare between the means.

\section{Calibration of AquaCrop to simulate the effect of the irrigation treatments on tomato crop production}

The complete theoretical concept of AquaCrop calibration is explained by Steduto et al. (2012). The latest version of AquaCrop model (version 6.0, June 2017) had been used in this study. The data of 2015/2016 and 2016/2017 seasons were used for calibration and validation, respectively. The calibrated parameters were primarily adjusted against fruits yield and biomass. Calibration started with the [T100] treatment and then the other irrigation treatments were included until the best-matching parameters applicable for full and deficit irrigation treatments were achieved. The calibrated model was then used for validation purposes without changing the calibrated parameters. Table (3) lists the summary of the final parameters set in the model. Additionally, during the calibration, the plant response to soil fertility was automatically calibrated at soil fertility level of "near optimal", that the plants received the optimal fertilization program. The relative cover of the weeds was considered as $5-10 \%$. The groundwater level is considered as $2.5 \mathrm{~m}$ depth from the soil surface, reference to the mean of the historical records of Shoubra El khima site. 
Finally, after all the model parameters adjustment, the model was run under "growing degree-days" mode.

Table (3): The crop growth parameters that used in the calibration process of AquaCrop model

\begin{tabular}{lc}
\multicolumn{1}{c}{ Crop growth and development parameter } & Value \\
\hline Transplanting date & 5 Oct \\
Row spacing [m] & 1.2 \\
Plant spacing [m] & 0.5 \\
Maximum canopy cover [\%] & 70 \\
Days after transplanting to recovery [day] & 8 \\
Days after transplanting to maximum canopy [day] & 60 \\
Days after transplanting to senescence [day] & 100 \\
Days after transplanting to maturity [day] & 130 \\
Days after transplanting to flowering [day] & 38 \\
Duration of flowering [day] & 42 \\
Maximum effective root depth [m] & 0.67 \\
Days after transplanting to maximum root depth [day] & 70 \\
Harvest Index (HI) [\%] & 65 \\
Base temperature [ ${ }^{\circ} \mathrm{C}$ ] & 9 \\
Upper temperature [ ${ }^{\circ} \mathrm{C}$ ] & 30 \\
The carbon sink strength [\%] & 0 \\
Extremely sensitive to water stress at canopy expansion & \\
(shape factor: linear) & \\
Sensitive to water stress at stomatal closure & \\
\hline
\end{tabular}

The calibration and validation process based on the comparison between the observed and the simulated values of the biomass and crop yield. The accuracy and performance of the model in calibration and validation was assessed based on the root mean square error (RMSE), and normalized root mean square error (NRMSE), calculated as follows:

$$
\begin{gathered}
R M S E=\sqrt{\frac{\sum\left(Y_{P}-Y_{O}\right)^{2}}{n}} \\
N R M S E=\frac{1}{\overline{Y_{O}}} \sqrt{\frac{\sum\left(Y_{P}-Y_{O}\right)^{2}}{n}} \times 100
\end{gathered}
$$

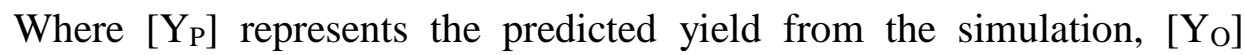
represents the observed yields, $\left[\overline{Y_{O}}\right]$ represents the mean of the observed 
yields, [n] represents the number of the year of the observations and simulations. In general, the simulation is better when the RMSE value is closer to zero, and the simulation can be considered excellent if the NRMSE is less than $10 \%$, good for $10-20 \%$, average quality for $20-30 \%$, and bad if the error value is greater than $30 \%$.

\section{RESULTS AND DISCUSSION}

\section{The applied irrigation applications under the investigated treatments}

Along the field experiment, the estimated $\mathrm{ET}_{\mathrm{o}}$ daily values ranged from 1.5 to $6.7 \mathrm{~mm} /$ day for the first growing season, and from 1.4 to $6.3 \mathrm{~mm} /$ day for the second season. The lowest $\mathrm{ET}_{\mathrm{o}}$ values were estimated at the second half of January, whereas the highest values were estimated during the second week of October. Based on the $\mathrm{ET}_{\mathrm{o}}$ and $\mathrm{Kc}$, the $\mathrm{ET}_{\mathrm{c}}$ values ranged from 1.0 to $4.0 \mathrm{~mm} /$ day for the first season, and 1.1 to $3.8 \mathrm{~mm}$ /day for the second season.

The total seasonal $\mathrm{ET}_{\mathrm{c}}$ was $385 \mathrm{~mm}$, as an average of the two seasons for T100 treatment (full irrigation). Table (4) shows the average total amount of irrigation water applied for tomato crop, throughout 24 applications along the season. It was $448 \mathrm{~mm}$ for T100 treatment (full irrigation), that approximately meets the mentioned irrigation requirements rate (400 to $800 \mathrm{~mm}$ ) recommended by Allen et al. (1998). The same table shows the deficit percentages of the investigated deficit irrigation treatments compared to the full irrigation treatment. The small difference (around 3\%) between the TS80, TC80 and TS60 treatments is remarkably obvious.

\section{The effect of applying irrigation treatments on the tomato crop yield}

As an average trend for all samples from the different irrigation treatments, the tomato fruits dry yield weight was about $7 \%$ from the fruits fresh yield weight. As shown in figure (1), the highest fruit yield was obtained by applying the full irrigation treatment, with an average of the two seasons of fresh yield equal to 105 tons/ha. Due to irrigation deficit, the yield decreased gradually by the decrease of the applied water, and reached to the lowest value under the TC60\% treatment, with an average fresh weight equal to 58 tons/ha. The results showed that there was no significant difference in total fresh yield between T100 and TS80 but there was significant difference between the other treatments. 
Table (4): The actual total applied irrigation applications [mm] under the investigated irrigation treatments:

\begin{tabular}{lccccc}
\hline & T100 & TS80 & TC80 & TS60 & TC60 \\
\hline $\begin{array}{l}\text { Water applied in first season } \\
\text { (2015/2016) [mm] }\end{array}$ & 458 & 376 & 370 & 359 & 275 \\
$\begin{array}{l}\text { Water applied in second season } \\
\text { (2016/2017) [mm] }\end{array}$ & 437 & 379 & 351 & 342 & 262 \\
Average water applied of the two & & & & & \\
seasons [mm] & 448 & 378 & 361 & 351 & 269 \\
Deficit percent (first season) [\%] & & 18 & 19 & 22 & 40 \\
Deficit percent (second season) [\%] & & 13 & 20 & 22 & 40 \\
Deficit percent (average) [\%] & & 16 & 19 & 22 & 40 \\
\hline
\end{tabular}
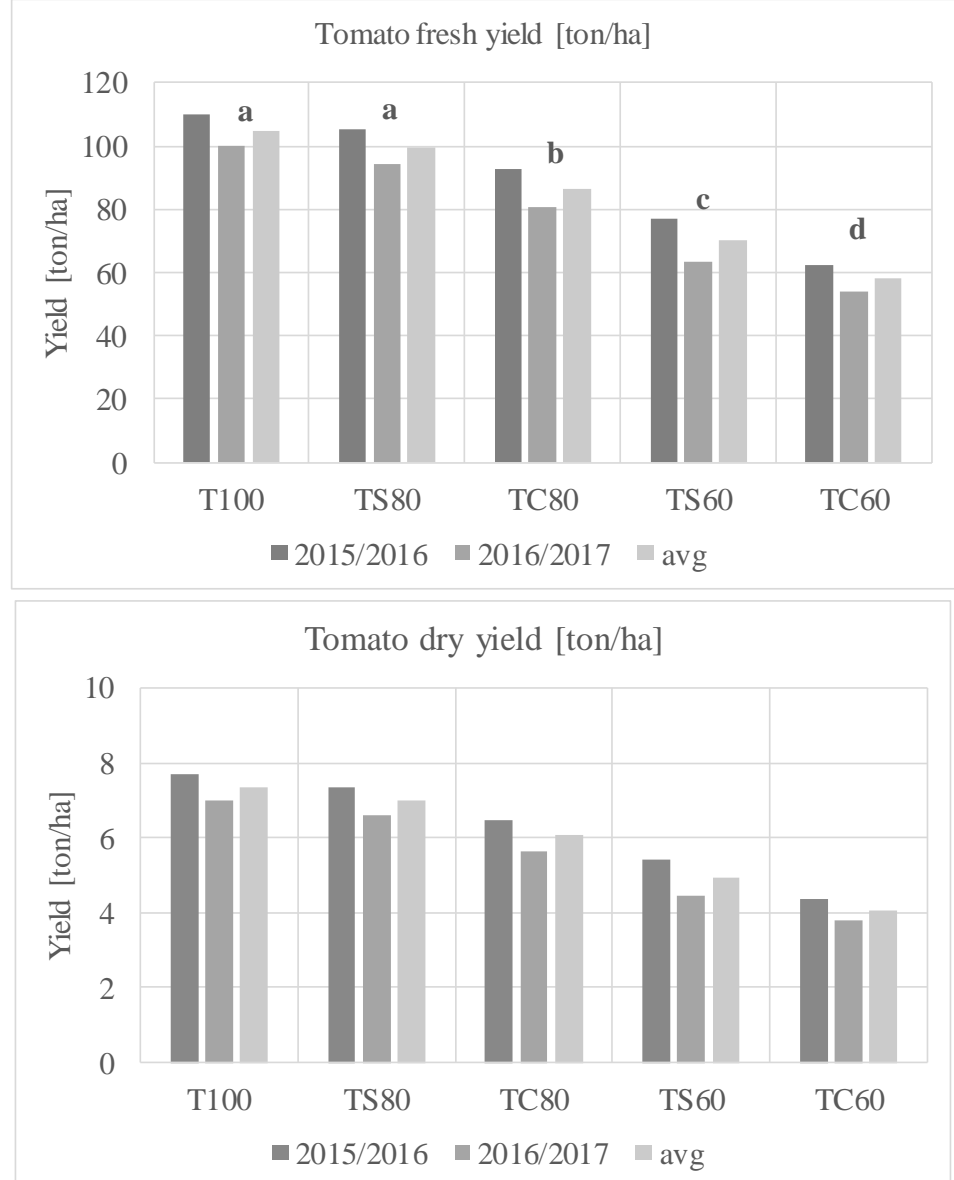

Figure (1): The tomato fruits fresh and dry yield under the investigated irrigation treatments (a, b, c, and $d$ are the significance levels) 
The reduction in the tomato yield due to water shortage ranged from $4 \%$ to $43 \%$ in 2015/2016 season, and from $6 \%$ to $46 \%$ in 2016/2017 season (table 5). The lowest reduction in the tomato yield was observed under TS $80 \%$ treatment, with an average reduction of 5\%, which was obtained with water saving equal to $16 \%$. One of the remarkable results shown in table (5), that the $3 \%$ decrease in the applied water between TC80 and TS60 treatments, almost doubled the reduction in the crop yield. As well as, applying deficit irrigation levels at initial and maturity crop stages only (noted TS treatments), caused lower reduction in the crop yield, compared to applying the same deficit level at all crop growing stages. Those results have similar trends with obtained by Kusua et al., (2014) and Li et al., (2010), which showed that the full irrigation for tomato crop during the whole growing season is better for higher yield and net income. However, in regions of water scarcity, the deficit irrigation approach should be assumed to accomplish economically sustainable tomato crop production.

\section{Table (5): The change [\%] observed in the tomato fruits fresh yield} due to the applications of deficit irrigation treatments compared to the fruits yield under full irrigation.

\begin{tabular}{|c|c|c|c|c|}
\hline & TS80 & TC80 & TS60 & TC60 \\
\hline $\begin{array}{l}\text { Change in crop yield for first season } \\
(2015 / 2016)[\%]\end{array}$ & -4 & -16 & -30 & -43 \\
\hline $\begin{array}{l}\text { Change in crop yield for second season } \\
(2016 / 2017)[\%]\end{array}$ & -6 & -19 & -36 & -46 \\
\hline $\begin{array}{l}\text { Average change in crop yield of the two } \\
\text { seasons [\%] }\end{array}$ & -5 & -17 & -33 & -45 \\
\hline
\end{tabular}

The effect of applying irrigation treatments on water productivity (WP) Water productivity (WP) values varied from 1.64 to $2.15 \mathrm{~kg} / \mathrm{m}^{3}$, which matched the range mentioned by Naika et al. (2005), and there were no significant differences in WP values between the investigated irrigation treatments. It was observed that water deficit treatments at of $80 \% \mathrm{ET}_{\mathrm{c}}$ resulted in higher water productivity, partly because there were lower evapotranspiration losses relative to the yield (Kusua et al., 2014). The highest value of WP was $2.20 \mathrm{~kg} / \mathrm{m}^{3}$ in the first season and $2.10 \mathrm{~kg} / \mathrm{m}^{3}$ in the second season, for TS80 treatment as shown in Figure (2). Applying deficit irrigation at both early and late stages of crop development could have a negative impact on canopy expansion and early senescence. This 
practice could obtain the required balance between irrigation application and WP, with lower levels of crop reduction compared to full season deficit practice. However, applying water deficit treatments of $60 \% \mathrm{ET}_{\mathrm{c}}$ lead to a reduction in WP reched to $-14 \%$, when applied at the intial and maturity stages only (Table 6). Under limitted water conditions, idintyfiying the optimal WP level is a high priority to sustain the balance between achieving the optimal crop yield and saving water at optiaml levels. Li et al., (2010) and Attaher (2012) stated that the combination between irrigation scheduling and deficit irrigation levels could improve water productivity of tomato crop to the optimal level, especially with deficit levels applied at the early and the late stages of crop development.

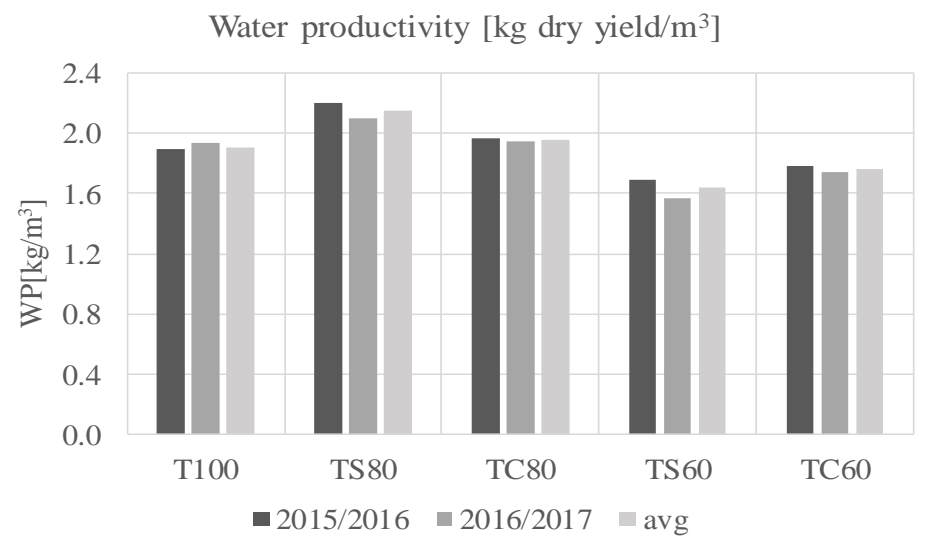

Figure (2): The tomato water productivity under the investigated irrigation treatments

Table (6): The change [\%] observed in the tomato water productivity (WP) due to the applications of deficit irrigation treatments compared to the WP under full irrigation.

\begin{tabular}{lcccc}
\hline & TS80 & TC80 & TS60 & TC60 \\
\hline Change in WP for first season (2015/2016) [\%] & 16 & 4 & -11 & -5 \\
Change in WP for second season (2016/2017) [\%] & 9 & 1 & -19 & -10 \\
Average Change in WP of the seasons [\%] & 13 & 2 & -14 & -8 \\
\hline
\end{tabular}

\section{The effect of applying irrigation treatments on the fruits quality}

Table (7) shows the effect of deficit irrigation treatments on tomato fruit quality. The water deficit significantly improved TSS as compared to full irrigation treatments. The lowest "TSS" was (5.1\% Brix) obtained by the full irrigation. This compared within the acceptable range of $3.5-5.5$ in fresh tomatoes according to (Patane` and Cosentino, 2010). 
Similarly, the "vitamin C" content for tomato fruit was greater under water deficit conditions. The lowest "vitamin $\mathrm{C}$ " content was $(28.7 \mathrm{mg}$ ascorbic acid/100 g FW) obtained by the full irrigation, while the highest vitamin $\mathrm{C}$ content was $(35.7 \mathrm{mg}$ ascorbic acid/100 $\mathrm{g} \mathrm{FW}$ ) for TC60\% treatment. Statistical difference in $\mathrm{pH}$ among treatments was less clear than for TSS and vitamin $\mathrm{C}$ content with water deficit conditions which is an important characteristic in terms of processing requirements. $\mathrm{pH}$ never exceeded 4.4 and the $\mathrm{pH}$ of good fruit is normally 4.0 to 4.5 according to (Patane and Cosentino, 2010).

Obviously, reducing the irrigation rate makes beneficial effects on fruit quality, in terms of "TSS" and vitamin "C" content with interesting implications for industrial purposes, and to human health benefits. Deficit irrigation has an important positive suggestion for processing tomato industry since it is well known that tomatoes with high TSS content could be obtained under water stress. (Abuarab et al., 2013).

Table (7): The effect of applying different deficit irrigation schemes on the fruits quality

\begin{tabular}{lcccccc}
\hline & T100 & TS80 & TC80 & TS60 & TC60 & Significance \\
\hline TSS ( ${ }^{\circ}$ Brix) & $5.1 \mathrm{a}$ & $5.7 \mathrm{~b}$ & $6.3 \mathrm{c}$ & $6.2 \mathrm{c}$ & $6.8 \mathrm{~d}$ & $*$ \\
$\mathrm{pH}$ & $4.48 \mathrm{a}$ & $4.44 \mathrm{a}$ & $4.46 \mathrm{a}$ & $4.39 \mathrm{a}$ & $4.46 \mathrm{a}$ & Ns \\
$\begin{array}{l}\text { Vitamin C (mg } \\
\begin{array}{l}\text { ascorbic } \\
\text { acid/100 g FW) }\end{array}\end{array}$ & $28.7 \mathrm{a}$ & $31.2 \mathrm{~b}$ & $33.6 \mathrm{c}$ & $33.2 \mathrm{c}$ & $35.7 \mathrm{~d}$ & $*$ \\
\hline
\end{tabular}

[ns]: not significant.

[*]: Significant at $\mathbf{p} \leq \mathbf{0 . 0 5}$ level.

Calibration of AquaCrop model to simulate the irrigation treatments on tomato crop production

AquaCrop model was calibrated in order to improve its performance to simulate the production of tomato crop under the local conditions of the current study. The calibration process of AquaCrop is less demanding than other system-wide and mechanistic cropping models, owing to the limited number of key parameters to be adjusted. The calibration process of AquaCrop is based on adjusting some crop parameters which represent the crop growth cycle, and the thresholds of stress factors.

Based on the crop parameters shown in table (3), the comparison between the simulated and the actual observed values of tomato biomass indicated a very well calibration of the model, with NRMSE values less than $11 \%$ under all irrigation treatments, as shown in Figure (3). 


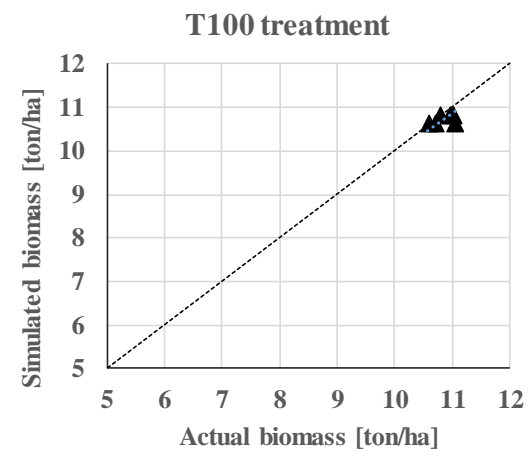

$\mathrm{RMSE}=0.202$ ton $/$ ha $\quad \mathrm{NRMSE}=1.9 \%$

TS80 treatment

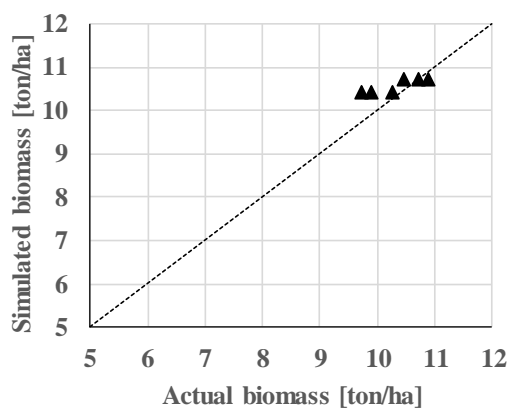

RMSE $=0.339$ ton $/$ ha $\quad$ NRMSE $=3.9 \%$

TS60 treatment

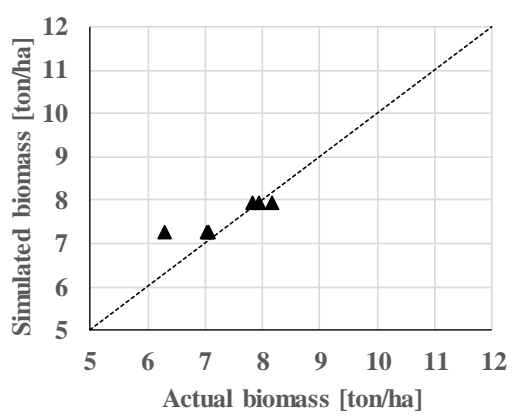

$\mathrm{RMSE}=0.429$ ton $/$ ha $\quad \mathrm{NRMSE}=5.8 \%$
TC80 treatment

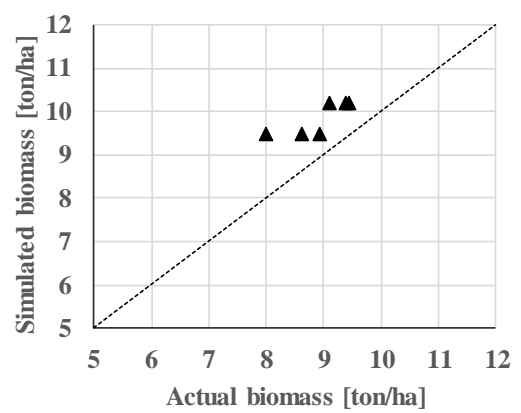

$\mathrm{RMSE}=0.964$ ton $/ \mathrm{ha} \quad \mathrm{NRMSE}=10.8 \%$

TC60 treatment

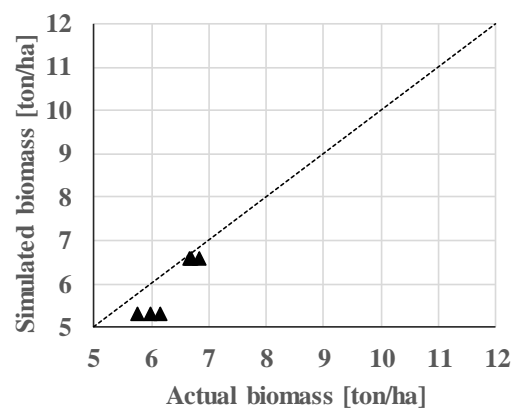

$\mathrm{RMSE}=0.490$ ton $/ \mathrm{ha} \quad \mathrm{NRMSE}=7.7 \%$

Figure (3): The actual biomass vs. the simulated biomass with the calibrated AquaCrop to simulate tomato crop

The simulated biomass was perfectly fitted with the actual biomass values under full irrigation treatment (T100) with RMSE equal to 0.202 ton/ha and NRMSE equal to $1.9 \%$. Whereas, the deficit irrigation treatment TC80 resulted in a less fitted case, that the model over- estimated the biomass with RMSE equal 0.964 ton/ha and NRMSE equal $10.8 \%$. 
Similarly, the differences between the simulated and the observed dry tomato yield were acceptable under all irrigation treatments, as presented in Figure (4). In general, AquaCrop model performed an excellent to good simulation for all irrigation treatments, with NRMSE ranging from $4.6 \%$ to $11.3 \%$, and RMSE ranging from 0.240 to 0.696 ton/ha.

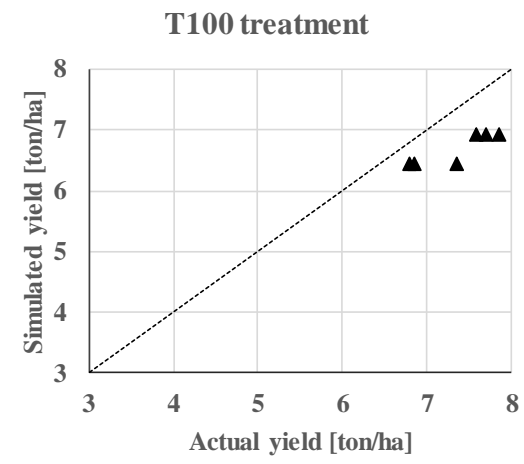

$\mathrm{RMSE}=0.696$ ton $/ \mathrm{ha} \quad \mathrm{NRMSE}=9.5 \%$

TS80 treatment

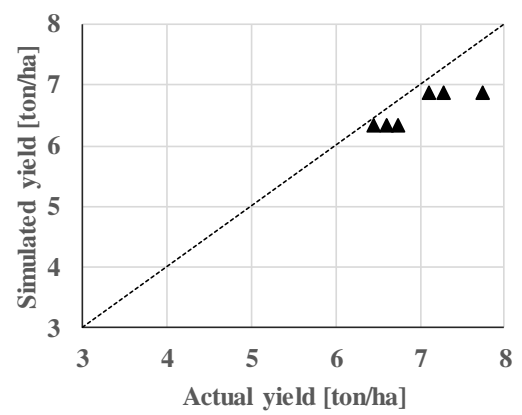

$\mathrm{RMSE}=0.441$ ton $/$ ha $\quad \mathrm{NRMSE}=6.3 \%$

TS60 treatment

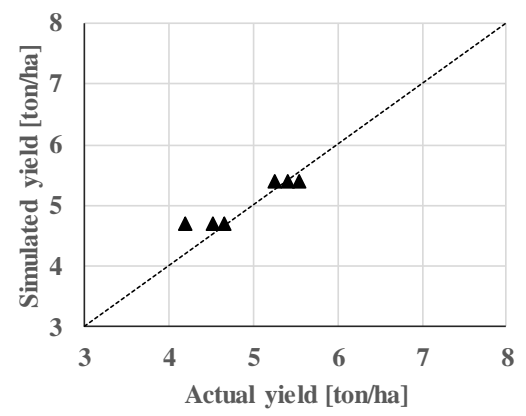

$\mathrm{RMSE}=0.240$ ton $/$ ha $\mathrm{NRMSE}=4.9 \%$
TC80 treatment

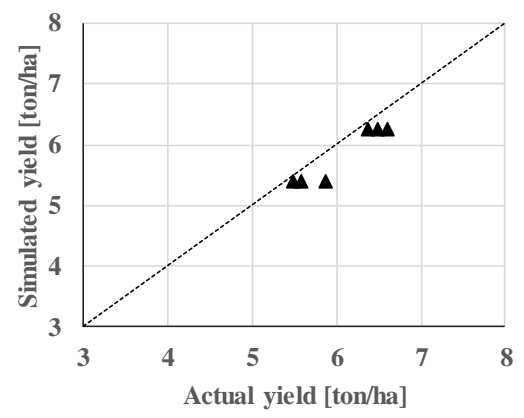

$\mathrm{RMSE}=0.278$ ton $/$ ha $\quad \mathrm{NRMSE}=4.6 \%$ TC60 treatment

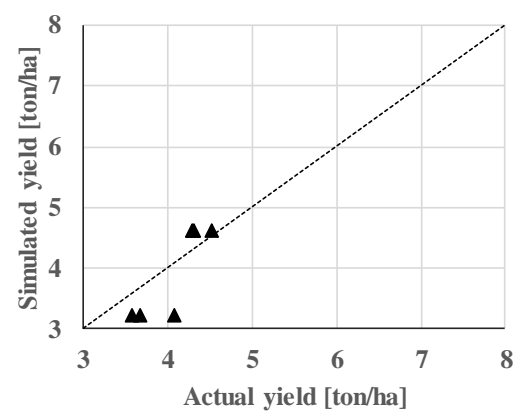

$\mathrm{RMSE}=0.463$ ton $/$ ha $\quad \mathrm{NRMSE}=11.3 \%$

Figure (4): The actual dry yield vs. the simulated dry yield with the calibrated AquaCrop to simulate tomato crop 
It could be concluded from the overall calibration and validation results, that AquaCrop model has a good ability to simulate the tomato crop biomass and yield under full and deficit irrigation conditions, which agreed with the outcomes concluded by Attaher (2012) and Katerji, et.al (2013). This could encourage the addressing of AquaCrop model as a good tool can be used with a high degree of reliability in practical management, strategic planning of irrigation, and water limited conditions.

\section{CONCLUSION}

Under arid climate and water shortage conditions, the balance between crop production and the irrigation application, is an essential parameter to optimize the irrigated agricultural system water productivity. Deficit irrigation strategies can improve water productivity, and fruits quality of tomato crop. The results showed that, among the investgated deficit irrigation schemes, applying diffecit irrigation schemes of $80 \% \mathrm{ET}_{\mathrm{c}}$ could reduce the amount of the irrigation water by $20 \%$ when the deficit applied at all crop growing stages, coupled with a yield reduction of about $17 \%$, and a slight increase in water productivity of about $2 \%$. Whereas, the same deficit level could save about $16 \%$ of the applied water when it applied only at initial and maturity growth stages, and decreased the crop yield by $5 \%$, which gave the highest WP of $2.15 \mathrm{~kg} / \mathrm{m}^{3}$, compared to the other investigated irrigation treatments.

Furthermore, AquaCrop model reveled a good performance in simulating tomato crop responses to deficit irrigation. The quality of the simulation performance is highly related to the quality of the data used in the local calibration process. Considering the simplicity and limited parameterization of AquaCrop compared to other crop growth models, it implies that the calibrated model would be a reliable tool for a wide range of water management strategies, crop yield, and biomass prediction scenarios under water-saving irrigation management in Egypt. Conducting more field trials aiming to produce and collect high quality field data, could strongly achieved by conducting more simulation studies using AquaCrop model, to investigate several management on-farm options to improve water productivity of the important crops. 


\section{REFERENCES}

Abuarab, M. E.; Shahien, M. M. and Hassan, A. M., 2013. Effect of Regulated Deficit Irrigation and Phosphorus Fertilizers on Yield, Water Use Efficiency and Total Soluble Solids of Tomato. ASABE Annual International Meeting Sponsored 10: 1295-1304.

Ahmadi, S. H.; Mosallaeepour, E.; Kamgar-Haghighi, A. A. and Sepaskhah, A. R., 2015. Modeling Maize Yield and Soil Water Content with AquaCrop Under Full and Deficit Irrigation Managements. Water Resources Management, 29(8), 2837-2853.

Allam, M.N.; El Gamal, F. and Hesham, M., 2005. Irrigation systems performance in Egypt. In: Lamaddalena N. (ed.), Lebdi F. (ed.), Todorovic M. (ed.), Bogliott i C. (ed.). Irrigation systems performance. Bari : CIHEAM, 2005. p. 85-98 (Options Méditerranéennes : Série B. Etudes et Recherches; n. 52).

Allen, R.G.; Pereira, L.S.; Raes, D. and Smith, M., 1998. Crop evapotranspiration: guidelines for computing crop water requirements. In: FAO Irrigation and Drainage Paper No. 56. FAO, Rome, Italy, 300 pp.

AOAC.,1984. Official Methods of Analysis. 14th edn. (S. Williams, ed.), pp. 844-846. Association of Official Analytical Chemists.Virginia.

Attaher, S. M., 2012. Developing on-farm irrigation strategies for current and future climate conditions at western bank of Lake Nasser. Misr. J. Ag. Eng., 29(2): 725-734.

El-Gindy, A. M.; Girgis, M. G. Z. and Arafa, Y. E., 2007. Effects of Biogation Technique on Biofertilizers performance and Tomato Yield. Proc. Of the $12^{\text {th }}$ Conference of Microbiology, Organized by The Egyptian Society of Applied Microbiol. (ESAM), Egypt.

FAO, 2012. ETo Calculator, Land and Water Digital Media Series No 36, FAO, Rome, Italy

Farre F. and Faci J.M., 2009. Deficit irrigation in maize for reducing agricultural water use in a Mediterranean environment. Agric. Water Manage. 96, 384-394.

Fereres E. and Soriano M.A., 2007. Deficit irrigation for predicting agricultural water use. J. Exp. Bot. 58,147-159. 
Geerts, S.; Raes, D.; Gracia, M.; Miranda, R.; Cusicanqui, J.A.; Taboada, C.; Mendoza, j.; Huanca, R.; Mamani, A.; Condori, O.; Mamani, J.; Morales, B.; Osco, V. and Steduto, P., 2009. Simulating yield response of Quinoa to water availability with AquaCrop. Agron. J. 101, 499-508.

Katerji, N.; Campi, P. and Mastrorilli, M., 2013. Productivity, evapotranspiration, and water use efficiency of corn and tomato crops simulated by AquaCrop under contrasting water stress conditions in the Mediterranean region. Agricultural Water Management, 130, 14-26

Kusua, H.; Turhana, A. and Demirb, A. O., 2014. The response of processing tomato to deficit irrigation at various phenological stages in a sub-humid environment. Agricultural Water Management $\mathrm{j}$, 133:92-103

Li, X.; Liub, F. ; Li, G.; Lina, Q. and Jensenb, C. R., 2010. Soil microbial response, water and nitrogen use by tomato under different irrigation regimes. Agricultural Water Management 98: 414-418.

MALR, 2017. Agricultural statistics. Economic Affairs Sector. Ministry of Agriculture and Land Reclamation. Egypt.

Molden, D.; T. Oweis; P. Steduto; P. Bindraban; M. A. Hanjra and J. Kijne, 2010. Improving Agricultural Water Productivity: Between Optimism and Caution. Agricultural Water Management, 97, 528535.

MWRI, 2016. Annual statistics of water resources. Ministry of water resources and irrigation, Egypt.

Naika, S.; Jeude, J. L.; Goffau, M.; Hilmi, M. and Printed, B. D., 2005. Cultivation of tomato, Wageningen, Netherlands .

Patane', C. and Cosentino, S.L., 2010. Effects of soil water deficit on yield and quality of processing tomato under a Mediterranean climate. Agricultural Water Management. 97: 131-138.

Pereira, L. S.; Oweis, T. and Zairi, A., 2002. Irrigation management under water scarcity. Agric. Water Manage. 57:175-206.

Pereira L.S.; Paredes P.; Sholpankulov E.D.; Inchenkova O.P.; Teodor P.R. and Horst M.G., 2009. Irrigation scheduling strategies for 
cotton to cope with water scarcity in the Fergana Valley, Central Asia. Agric. Water Manage. 96, 723-735.

Ragab, R., 2014. A note on water use efficiency and water productivity. Water4Crops.1-11.

Steduto, P.; Hsiao, T.C.; Fereres, E. and Raes, D., 2012. Crop Yield Response to Water. FAO Irrigation and Drainage Paper Nr. 66. Rome, Italy

Steduto P.; Hsiao T.C.; Raes D. and Fereres E., 2009. AquaCrop- The FAO crop model to simulate yield response to water. I.Concepts.Agron.J.101, 426-437.

Stricevic, R.; Cosic, M.; Djurovic, N.; Pejic, B.; and Maksimovic, L., 2011. Assessment of the FAO AquaCrop model in the simulation of rainfed and supplementally irrigated maize, sugar beet and sunflower. Agricultural Water Management, 98(10), 1615-1621.

Toumi, J.; Er-Raki, S.; Ezzahar, J.; Khabba, S.; Jarlan, L. and Chehbouni, A., 2016. Performance assessment of AquaCrop model for estimating evapotranspiration, soil water content and grain yield of winter wheat in Tensift Al Haouz (Morocco): Application to irrigation management. Agricultural Water Management, 163, 219235 .

\section{الملخص العربي}
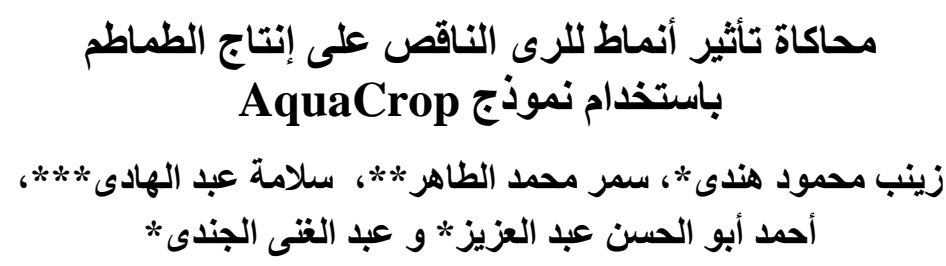

تبحث الدر اسة الإمكانيات المختلفة لتحسين انتاجية مياه الرى الحقلى لإنتاج محصول الطماطم،

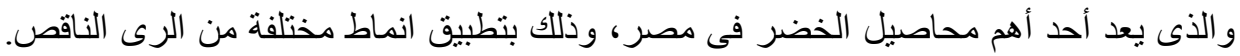

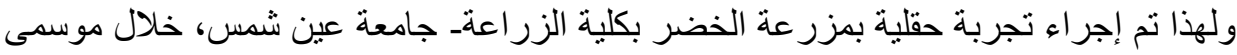

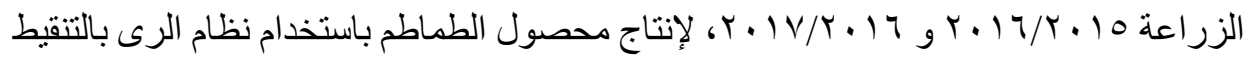
و تطبيق انماط مختلفة من الرى الناقص.

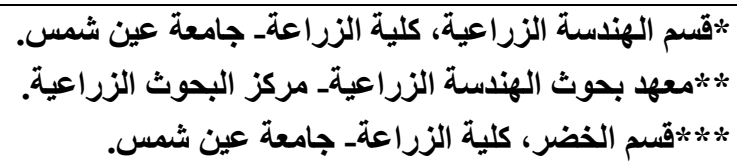




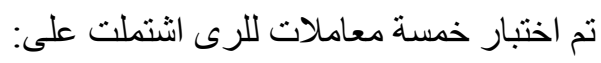

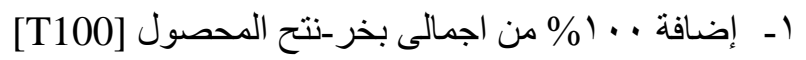

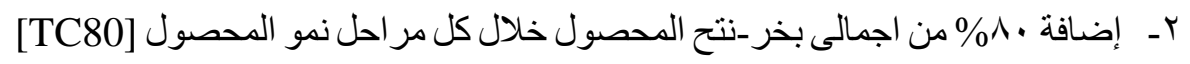

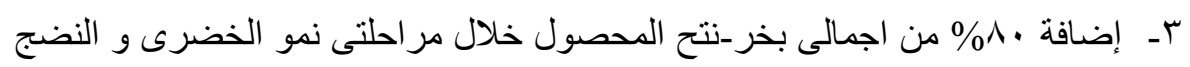

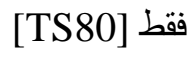

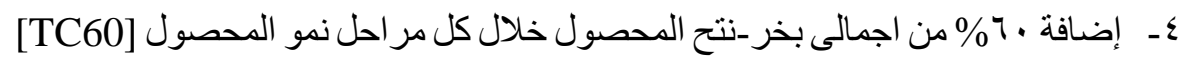

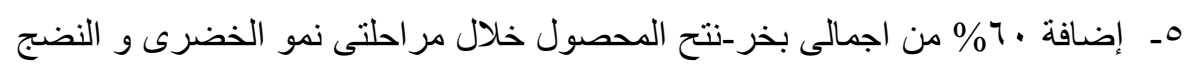

فTS60] فقا ف

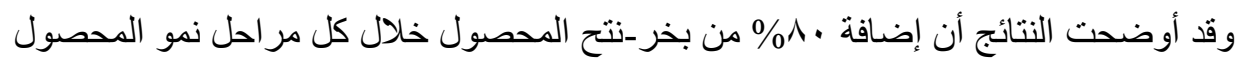

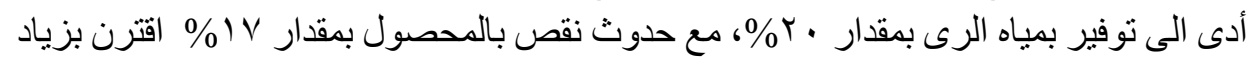

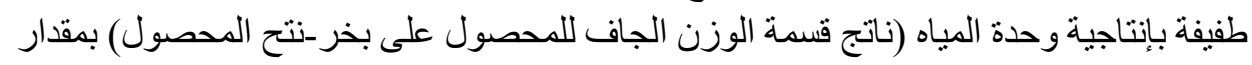

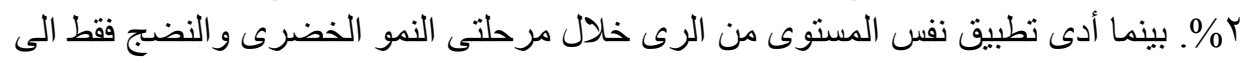

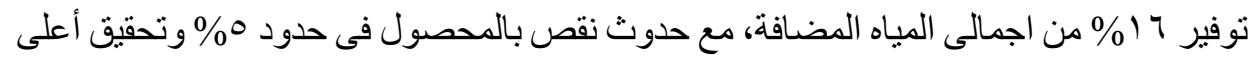

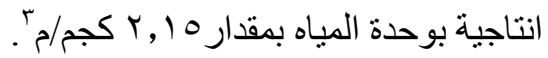

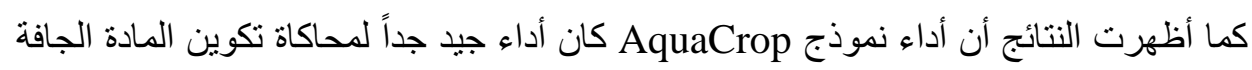

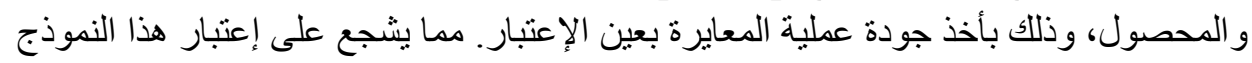

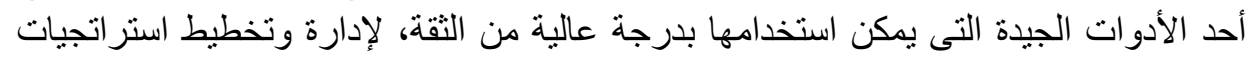

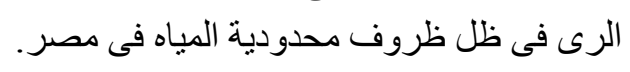

